\title{
Model Wheat Genotypes as Tools to Uncover Effective Defense Mechanisms Against the Hemibiotrophic Fungus Bipolaris sorokiniana
}

\author{
Aloysius Ebelechukwu Ibeagha, Ralph Hückelhoven, Patrick Schäfer, Devendra Pal Singh, and Karl-Heinz Kogel
}

First, second, third, and fifth authors: Institute of Phytopathology and Applied Zoology, Interdisciplinary Research Centre for Environmental Sciences, Justus-Liebig-University, Heinrich-Buff-Ring 26-32, D-35392, Giessen, Germany; and fourth author: Directorate of Wheat Research (DWR), Kunjpura Road, Karnal, Haryana, 132001, India. Accepted for publication 11 January 2005.

\begin{abstract}
Ibeagha, A. E., Hückelhoven, R., Schäfer, P., Singh, D. P., and Kogel, K.-H. 2005. Model wheat genotypes as tools to uncover effective defense mechanisms against the hemibiotrophic fungus Bipolaris sorokiniana. Phytopathology 95:528-532.

We investigated the interaction of several differentially resistant wheat genotypes with the hemibiotrophic phytopathogenic fungus Bipolaris sorokiniana (teleomorph Cochliobolus sativus). Wheat genotypes Yangmai 6, M 3 (W7976), Shanghai 4, and Chirya 7 showed higher levels of resistance compared with cv. Sonalika, used as a susceptible control. In a quantitative microscopic inspection, we found that fungal penetration into

the epidermal layer failed mostly through a cell wall-associated defense mechanism. In cases where the fungus successfully overcame epidermal defense, its spread within the mesophyll tissue (necrotrophic phase) was restricted in the more resistant genotypes. Epidermal cell wall-associated defense, spreading as well as the extent of electrolyte leakage of infected tissue, correlated well with field resistance. We propose that cellular host responses such as formation of cell wall appositions as well as the degree of early mesophyll spreading of fungal hyphae are indicative of the defense potential of the respective host genotype and, therefore, could be used for the characterization of new spot blotch resistance traits in cereals.
\end{abstract}

Cochliobolus sativus [(Ito \& Kuribayashi) Drechs. ex Dastur; anamorph Bipolaris sorokiniana (Sacc.) Shoemaker] is a serious pathogen of wheat and barley in North and South America and several countries of Asia (7,12,19,22,29,32, for review see 21). Among the variety of symptoms produced by this pathogen on all plant parts, the foliar spot blotch phase has emerged as a major biotic stress limiting commercial production of wheat $(8,10)$ and barley (1). In fact, spot blotch has become a major production constraint in South Asia's intensive cropping systems where nearly 12 million hectares of land under cultivation are affected $(25,30)$. Effective control of spot blotch can be achieved by the introduction of resistant cultivars as an important component of integrated disease management (24). Hence, the search for parental stocks possessing an adequate level of resistance to $B$. sorokiniana is essential.

The objective of this study was to gather information on the mechanism(s) of resistance of elite wheat against $B$. sorokiniana. The fungus can grow on the plant without producing symptoms, but mainly causes necrotic lesions on the leaf (6). Pathogenesis includes germination of conidia on the leaf surface and formation of an appressorium at the tip of the germ tube that supports direct penetration through the host cuticle $(3,20,21)$. The apparently biotrophic growth phase is primarily confined to a single epidermal cell invaded by infection hyphae, whereas the necrotrophic growth phase starts upon invasion of the mesophyll tissue fol-

Corresponding author: K.-H. Kogel

E-mail address: Karl-Heinz.Kogel@agrar.uni-giessen.de

* The $e$-Xtra logo stands for "electronic extra" and indicates that the online version contains supplemental material not included in the print edition. The online version contains a figure showing the interaction phenotypes of different wheat genotypes with Bipolaris sorokiniana.

DOI: 10.1094/PHYTO-95-0528

(C) 2005 The American Phytopathological Society lowed by host cell death, which appears to be a consequence of toxin secretion $(2,21,26)$.

Few studies have been published on the cellular and molecular factors contributing to resistance to B. sorokiniana $(6,21,28)$. $\mathrm{Re}$ cently, it was demonstrated that the barley Mlo gene, which is a susceptibility factor supporting growth of the biotrophic fungus Blumeria graminis f. sp. hordei and is implicated in cell survival $(5,11,16)$, contributes to barley background resistance to $B$. sorokiniana and other hemibiotrophic pathogens $(18,20)$. The impact of host-generated hydrogen peroxide $\left(\mathrm{H}_{2} \mathrm{O}_{2}\right)$ on early infection stages of $B$. sorokiniana has been analyzed by subcellular $\mathrm{H}_{2} \mathrm{O}_{2}$ detection in tissues infiltrated with diaminobenzidine (DAB). Intriguingly, $\mathrm{H}_{2} \mathrm{O}_{2}$ accumulates strongly in association with an unsuccessful fungal attack in the epidermis as well as in association with successful fungal growth in the barley mesophyll. However, the definitive role of $\mathrm{H}_{2} \mathrm{O}_{2}$ in defense to $B$. sorokiniana is still unclear $(16,28)$. In the present study, we undertook an investigation of the defense responses of wheat genotypes Yangmai 6, M 3, Shanghai 4, and Chirya 7, all of which are being integrated in international breeding programs aimed at developing spot blotch resistant wheat cultivars. We propose that cellular host responses such as formation of cell wall appositions as well as the degree of early mesophyll spreading of fungal hyphae are indicative of the defense potential of the respective host genotype and, therefore, could be used for the characterization of new spot blotch resistance traits in cereals.

\section{MATERIALS AND METHODS}

Host and pathogen. Wheat genotypes obtained from the International Maize and Wheat Improvement Center (CIMMYT), Mexico, and the Directorate of Wheat Research (DWR), India, viz. Yangmai 6, M 3 (W7976), Shanghai 4, Chirya 7, Longmai 10, Ning 8201, Suzhoe 8, Chirya 1, Ciano T-79, and Sonalika (9) 
were used. The sources and pedigrees of the germ plasm are provided in Table 1.

Plants were grown in growth chambers at $18^{\circ} \mathrm{C}, 60 \%$ relative humidity, and a $16-\mathrm{h}$ photoperiod $\left(100 \mu \mathrm{E} / \mathrm{m}^{-2} \mathrm{~s}^{-1}\right)$. B. sorokiniana $(B s-k n 2$ [20]) was originally isolated from the flag leaf of wheat Sonalika growing under natural conditions at Banaras, India, during April 1999, and is available from the culture collection of the Institute of Phytopathology and Applied Zoology, Justus-LiebigUniversity, Giessen, Germany. The single conidial isolate was produced following the method of Hetzler (13). Conidia from monoconidial cultures were transferred to a $30 \%$ V8 agar and incubated at room temperature under a 12-h photoperiod $\left(100 \mu \mathrm{E} / \mathrm{m}^{-2} \mathrm{~s}^{-1}\right)$. After 7 days, petri dishes were flooded with distilled water containing $0.02 \%$ Tween 20 . The conidia were scraped from the surface with a spatula and then filtered through two layers of muslin cloth to obtain a conidial suspension without mycelium.

Inoculation. Leaf segments were harvested and laid flat by fixing their ends on the surface of a steel sheet. A suspension containing approximately 20,000 conidia per $\mathrm{ml}$ of water supplemented with $0.02 \%$ Tween 20 was sprayed onto the segments. Inoculated segments were placed onto a 2-mm-thick layer of $0.5 \%$ water agar (adding 0.6 parts per million of benzimidazole) in a plastic dish closed tightly with a lid. This low concentration of benzimidazole delayed leaf senescence but did not affect the fungus. The dishes were placed in a growth chamber at $25^{\circ} \mathrm{C}$ and a 16 -h photoperiod $\left(100 \mu \mathrm{E} / \mathrm{m}^{-2} \mathrm{~s}^{-1}\right)$. The lower $4-\mathrm{cm}$ portion of first leaf segments and/or the middle 6 -cm portion of third leaf segments were evaluated $48 \mathrm{~h}$ after inoculation (hai) by a binocular microscope for the number of conidia and lesions.

Microscopy and histochemical assay for $\mathrm{H}_{2} \mathrm{O}_{2}$ detection. Epifluorescence microscopy (Axioplan Microscope, Zeiss, Jena, Germany) in combination with the fluorescent brightener Calcofluor (Sigma-Aldrich, Munich, Germany) was used to reveal the interaction phenotypes. Calcofluor has been used for cell and hyphal wall detection $(27,28)$ and facilitates the location of fungal penetration sites in leaf tissue. Leaf fixation and microscopy were conducted as described by Hückelhoven and Kogel (15). Inoculated segments taken at 20,40, and 60 hai were fixed in $0.15 \%$ trichloroacetic acid (wt/vol) in ethanol/chloroform (4:1, vol/vol). Fixed segments were later washed two times for 15 min with $50 \%$ ethanol, two times for $15 \mathrm{~min}$ with $50 \mathrm{mM} \mathrm{NaOH}$, and three times for $10 \mathrm{~min}$ with distilled water followed by 30-min incubation in $0.1 \mathrm{M}$ Tris- $\mathrm{HCl}(\mathrm{pH} \mathrm{8.5)}$. After this step, segments were stained for $5 \mathrm{~min}$ with $0.3 \%$ (wt/vol) Calcofluor and finally washed four times for 10 min with distilled water. Leaf segments were stored in $50 \%$ glycerol. Papilla-like structures with a halo appear light blue under UV excitation ( $385 \mathrm{~nm}$, emission 420 to $460 \mathrm{~nm}$, data not shown), probably indicating cell wall alterations by the activity of fungal hydrolases. Detection of $\mathrm{H}_{2} \mathrm{O}_{2}$ was carried out by an endogenous peroxidase-dependent in situ staining procedure with
3,3-DAB (Sigma-Aldrich) (31). Leaves were infiltrated with DAB $(1 \mathrm{mg} / \mathrm{ml}), \mathrm{pH} 3.8$ (adjusted with $\mathrm{HCl}$ ).

Quantification of fungal development and defense responses. The number of brown necrotic lesions observed divided by the number of conidia observed under the binocular microscope was calculated and expressed as lesions per conidia (in percent). Detection of papilla-like structures and the hypersensitive reaction (HR) has been described $(21,28)$. Whole-cell DAB staining or yellow-green whole-cell autofluorescence, respectively, under blue light excitation (excitation: 460 to $480 \mathrm{~nm}$, emission: longpass $510 \mathrm{~nm}$ ) was used to detect the HR. To detect quantitative differences in fungal ramification within the mesophyll, a spreading factor was defined by assessing the range of the most distant tips of inter- and intracellular hyphae at one infection site (28).

Electrolyte leakage of leaf segments. Detached leaf segments were inoculated with 50,000 conidia per $\mathrm{ml}$ and incubated at $24^{\circ} \mathrm{C}$ and a $16-\mathrm{h}$ photoperiod $\left(30 \mu \mathrm{E} / \mathrm{m}^{-2} \mathrm{~s}^{-1}\right)$ in transparent plastic dishes containing $0.7 \%$ water agar supplemented with 0.6 parts per million of benzimidazole and closed tightly with a lid. Each treatment comprised 10 leaf samples divided into two replicates of five leaf sections each. After incubation for $48 \mathrm{~h}$, a razor blade was used to cut a $2.5 \mathrm{~cm}$ leaf section of each leaf. The electrolyte leakage assay was carried out as described by Kwon et al. (23).

\section{RESULTS}

Initial screening for resistance. The level of seedling and adult plant resistance to $B$. sorokiniana, as assessed by lesion density and area under the disease progress curve in the field, as well as the origin and pedigrees of germ plasm are shown in Table 1. We analyzed disease symptoms caused by isolate $B s-k n 2$ after conidial spray inoculation of Longmai 10, Chirya 7, Yangmai 6, Shanghai 4, M 3, and Yangmai 6. Initially, we screened detached segments from the third leaves (21-day-old seedlings) and first leaves (10-day-old seedlings) and found no differences in the interaction phenotypes on different leaf types (data not shown). Figure 1 shows data obtained in an independent inoculation experiment with first leaf segments of 10-day-old wheat seedlings. Sonalika exhibited highest and Yangmai 6 exhibited lowest numbers of spot blotch lesions per leaf segment while Longmai 10, Chirya 7, M 3, and Shanghai 4 showed an intermediate response (Fig. 1).

Pre-infection defense responses. A microscopic survey showed that the fungus penetrates epidermal cells through the anticlinal cell walls and subsequently invades mesophyll tissue from hyphae produced inside epidermal cells. We termed fungal penetration into epidermal cells "successful penetration" and invasion of the mesophyll tissue "successful infection."

We comparatively analyzed the epidermal penetration resistance of cvs. Sonalika, M 3, and Yangmai 6. Pre-infection defense as defined here includes nonpenetrated cell wall appositions

TABLE 1. Levels of field resistance to Bipolaris sorokiniana, origin, and pedigrees of wheat genotypes used in the study

\begin{tabular}{|c|c|c|c|}
\hline Genotype & Level of field resistance ${ }^{a}$ & Origin & Pedigree \\
\hline Sonalika ${ }^{\text {cc }}$ & $\mathrm{S}$ & India & II53.388/AN//YT54/N10B/3/LR/4/B4946.A.4.18.2.1Y/Y53//3*Y50 \\
\hline Chirya $1^{\mathrm{d}}$ & MR & Mexico & CS/TH.CU//GLEN/3/ALD/PVN/4/NINGMAI4/OLESON//ALD/YANGMAI 4 \\
\hline Longmai $10^{\mathrm{d}}$ & MR & China & DONGNONG 101/LONG 70.663 \\
\hline Shanghai $4^{\mathrm{d}}$ & MR & China & Unknown \\
\hline M $3\left(\right.$ W7976) ${ }^{\mathrm{e}}$ & $\mathrm{R}$ & CIMMYT & Cando/R143//Mexi 's'/3/T. taushii (CI22) \\
\hline Yangmai $6^{\mathrm{df}}$ & $\mathrm{R}$ & China & Unknown \\
\hline
\end{tabular}

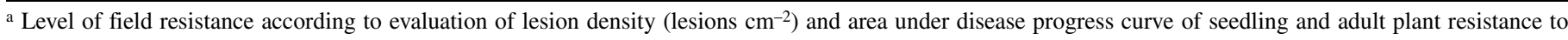
spot blotch. S, susceptible; MR, moderately resistant; R, resistant.

b Duveiller et al. (8).

${ }^{c}$ Duveiller and Garciá Altamirano (9).

${ }^{\mathrm{d}}$ E. Duveiller (personal communication).

e D. P. Singh (unpublished data).

f Sharma et al. (29). 
(CWA) beneath sites of fungal attack and epidermal HR, both resulting in failure of fungal development and invasion of the mesophyll tissue. The highest frequency of CWA was found in Yangmai 6 at all times (20, 40, and 60 hai) (Fig. 2). The CWA frequencies increased with time suggesting that subsequent penetration attempts are less successful than early ones. The frequencies of nonpenetrated epidermal cells undergoing an HR showed no differences at $20 \mathrm{~h}$ among all genotypes (Fig. 3). By 40 and 60 hai, however, HR frequencies were even lower in the resistant Yangmai 6, which can be explained by the increase in CWA with newly emerging appressoria (Fig. 2). In some cases, fungal growth was arrested by a host cell death after fungal penetration (postpenetration HR [PPHR]) when infection hyphae had been formed (Fig. 4). PPHR frequencies were also lowest in Yangmai 6.

Postinfection defense responses. We determined the rates of successful fungal infection of the mesophyll layer (Fig. 5). The highest infection rate was found in Sonalika. Mesophyll tissue of M 3 was invaded at the late time point (60 hai), and Yangmai 6 was only rarely invaded by fungal hyphae. To detect quantitative

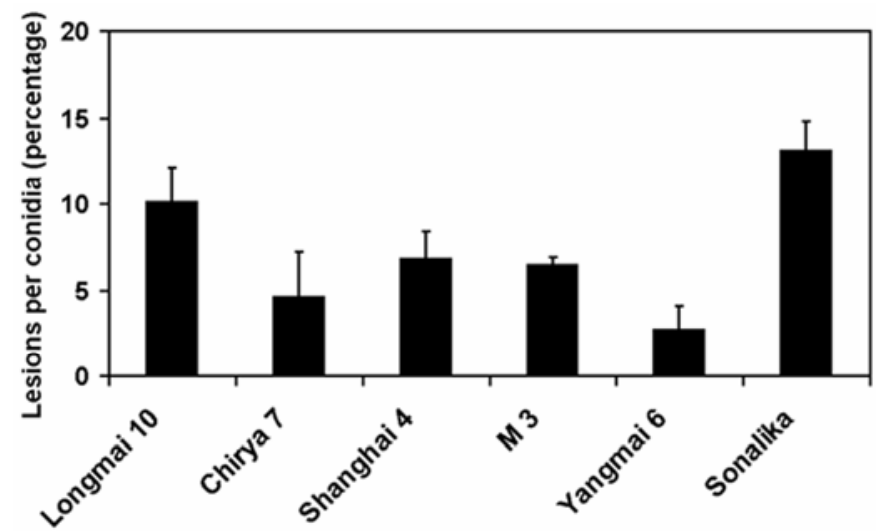

Fig. 1. Relative inoculum efficiency on different wheat genotypes. Binocular microscopy evaluation of spot blotch formation of Bipolaris sorokiniana isolate $B s-k n 2$ on 10-day-old first leaves from various wheat genotypes at $48 \mathrm{~h}$ after inoculation. Displayed is the percentage of conidia causing a visible necrotic lesion on a 4-cm-long leaf segment after spray inoculation with a solution of 20,000 conidia per $\mathrm{ml}$. Ten leaf segments from each genotype were used with the mean from three independent replications reported. The experiment was repeated two times with similar results. Vertical bars represent standard deviation of the means.

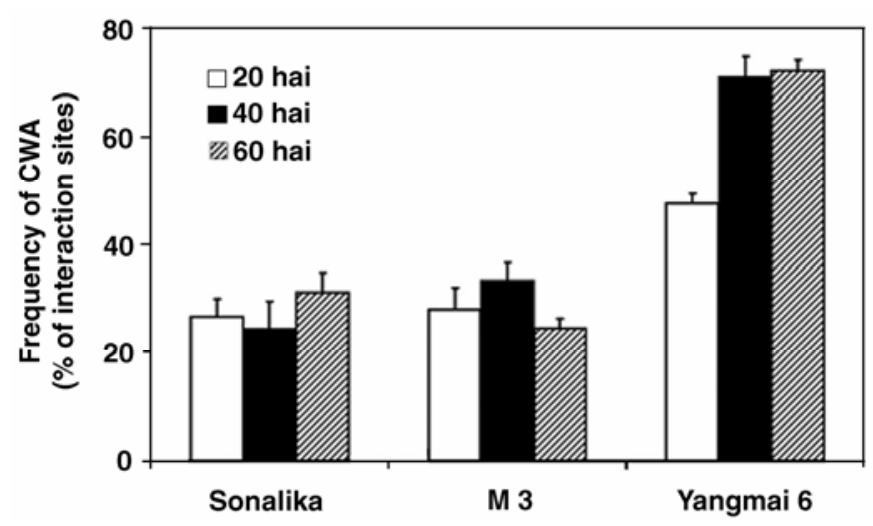

Fig. 2. Relative cell wall apposition formation in spot blotch-inoculated select wheat genotypes. Frequencies of cell wall appositions (CWAs) formed in response to Bipolaris sorokiniana, isolate Bs-kn2, in wheat genotypes Sonalika, M 3, and Yangmai 6 at 20, 40, and $60 \mathrm{~h}$ after inoculation (hai). Leaf segments of 10-day-old first leaves were inoculated with 50,000 B. sorokiniana conidia per $\mathrm{ml}$. Thirty interaction sites were evaluated per leaf. The mean of three leaves for each genotype and inspection time point is displayed. The experiment was repeated two times with similar results. Vertical bars represent standard deviation of the mean. differences in fungal spreading within the mesophyll, we analyzed the spreading factor by assessing the range of the most distant tips of inter- and intracellular hyphae at each infection site. A steady increase in the spreading factor of Sonalika from 20 to 60 hai was observed and differed from that of M 3 and Yangmai 6 (Fig. 6). Yangmai 6 exerted the lowest spreading factor, clearly reflecting the spot blotch resistance under field conditions.

Electrolyte leakage. We evaluated the extent of host cell collapse by measuring electrolyte leakage in leaf segments (Table 2). We found a close association between the extent of electrolyte leakage and field susceptibility. Wheat genotypes developing severe necrosis in response to fungal attack exhibited enhanced ion leakage into the apoplastic fluid. Leakage was extremely high in the susceptible genotype Sonalika.

\section{DISCUSSION}

The objective of this study was to elucidate cellular defense responses to $B$. sorokiniana in wheat genotypes currently used

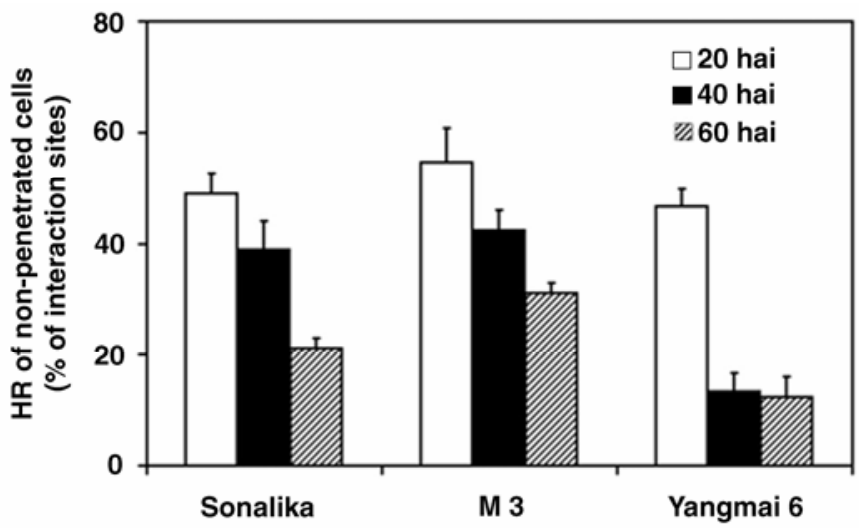

Fig. 3. Relative prepenetration hypersensitive reactions (HR) in spot blotchinoculated select wheat genotypes. Frequencies of HR in nonpenetrated epidermal cells of wheat genotypes Sonalika, M 3, and Yangmai 6 in response to Bipolaris sorokiniana, isolate Bs-kn2, at 20,40, and $60 \mathrm{~h}$ after inoculation (hai) as measured by epifluorescence microscopy. Thirty interaction sites were evaluated per leaf. The mean of three leaves for each genotype and inspection time point is displayed. The experiment was repeated two times with similar results. Vertical bars represent standard deviation of the mean.

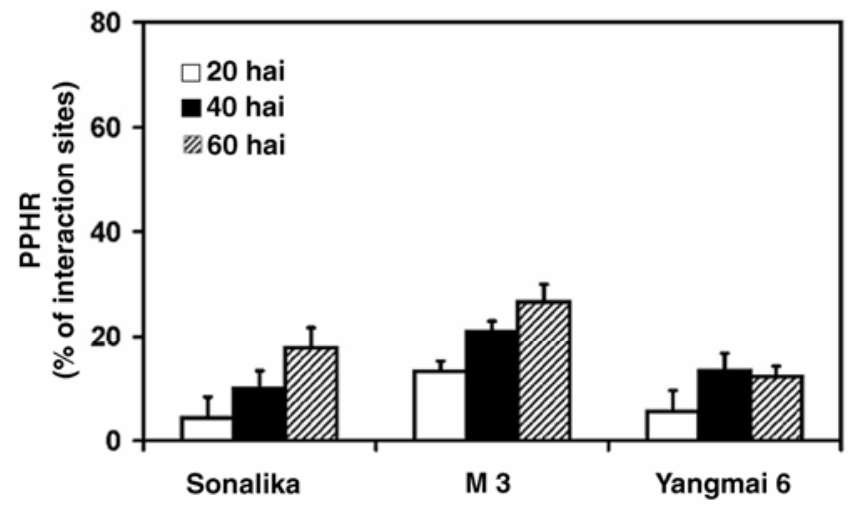

Fig. 4. Relative postpenetration hypersensitive reactions (PPHR) in spot blotch-inoculated select wheat genotypes. Frequencies of PPHR in attacked epidermal cells of wheat genotypes Sonalika, M 3, and Yangmai 6 in response to Bipolaris sorokiniana, isolate Bs-kn2, at 20,40 , and $60 \mathrm{~h}$ after inoculation (hai). PPHR was observed as whole-cell autofluorescence of penetrated cells leading to encapsulation of fungal infection hyphae and a subsequent arrest of fungal development. Thirty interaction sites were evaluated per leaf. The mean of three leaves for each genotype and inspection time point is displayed. The experiment was repeated two times with similar results. Vertical bars represent standard deviation of the mean. 
in international breeding programs. Our data indicate close associations between adult plant resistance in the field and reduced fungal penetration into epidermal cells, reduced infection of and spreading within mesophyll tissue as well as low ion leakage.

B. sorokiniana exerts a hemibiotrophic life style in its interaction with barley; that is, it shows distinct biotrophic and subsequent necrotrophic growth phases (28). The same applies for its interaction with wheat as demonstrated here. We show that resistance of wheat to B. sorokiniana is primarily attributed to penetration resistance due to a CWA-associated defense mechanism. Moreover, we detected two types of cell death: a frequent HR of attacked but nonpenetrated cells and, more rarely, a PPHR leading to an encapsulation of infection hyphae. HR frequencies, however, do not explain differences in resistance to $B$. sorokiniana among the genotypes. Rather consistently, HR occurs in all genotypes at a similar extent. Therefore, one can speculate that HR is a component of basal resistance to $B$. sorokiniana in wheat.

Penetration resistance at the epidermal stage is closely associated with local generation of $\mathrm{H}_{2} \mathrm{O}_{2}$ in CWA and/or in whole cells, visualized by DAB staining. This finding is reminiscent of defense responses of cereals toward the biotrophic powdery mildew fungus, Blumeria graminis $(14,17)$, thus supporting the view that $B$. sorokiniana, at very early infection stages, exerts a biotrophic life style $(6,28)$.

Once the fungus has successfully colonized epidermal cells, blocking of mesophyll invasion and inhibition of spreading within the mesophyll tissue represent subsequent defense mechanism(s). It appears that invasion by itself, as well as spreading after invasion, is subject to distinct defense reactions exerted by more resistant wheat genotypes (Figs. 5 and 6). Development of the fungus within the mesophyll seems to be indicative of the potential of a plant to restrict the pathogen. Hence, the spreading factor is a reliable character for the resistance potential of a cultivar. Importantly, the spreading factor associates with lesion development (Figs. 1 and 6) as well as with the number of collapsed mesophyll cells per lesion in both wheat (data not shown) and barley (28).

Once the fungus has entered the mesophyll, cell death appears to trail the expanding hyphae, which proliferate from the site of penetration to neighboring cells. In this phase, cell death seems ineffective in blocking the pathogen. It remains unclear whether mesophyll cell death is a response under host control or, alterna-

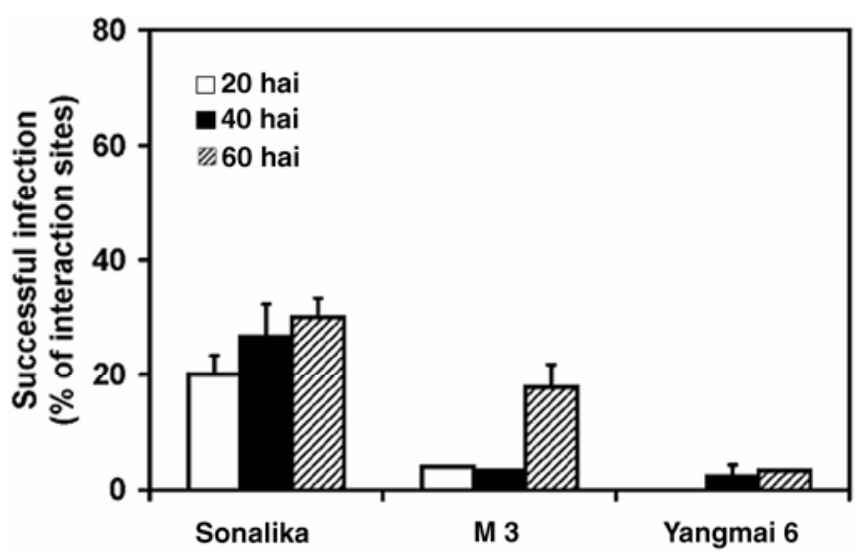

Fig. 5. Relative rate of mesophyll colonization in spot blotch-inoculated select wheat genotypes. Successful mesophyll infection of wheat genotypes Sonalika, M 3, and Yangmai 6 by Bipolaris sorokiniana, isolate Bs-kn2, at 20, 40, and $60 \mathrm{~h}$ after inoculation (hai). Fungal attack was termed "successful infection" when the intracellular or intercellular hyphae were visible in the mesophyll layer. Thirty interaction sites were evaluated per leaf. The mean of three leaves for each genotype and inspection time point is displayed. The experiment was repeated two times with similar results. Vertical bars represent standard deviation of the mean. tively, toxin-provoked and out of host control (4). Interestingly, the barley albino mutant albostrians expresses a white leaf phenotype that is super-susceptible to B. sorokiniana. In this mutant, fungal spreading within the mesophyll is strongly enhanced compared to the green leaves even though mesophyll cell death in albostrians was not detectable (28). This result is an argument in favor of cell death to restrict fungal development in the mesophyll. Alternatively, the speed in the occurrence of mesophyll cell death is pivotal to stop fungal cell-to-cell movement. In such a situation, the necrotrophic growth phase of B. sorokiniana would reflect a pathogenic strategy to cope with plant cell death-associated defense (28). It remains unclear whether during the necrotrophic phase host-generated $\mathrm{H}_{2} \mathrm{O}_{2}$ contributes to resistance or successful pathogenesis. Again, data obtained in the albostrians mutant indicate that $\mathrm{H}_{2} \mathrm{O}_{2}$ is not required for fungal pathogenesis (28).

Our data show that resistance to Yangmai 6 is clearly associated on the cellular level with enhanced CWA formation, reduced mesophyll invasion, and reduced spreading within the mesophyll. These cellular defense responses are also found in the other wheat lines, including highly susceptible Sonalika, though to a much lower frequency. In Yangmai 6, early defense reactions conditioned the leaf for even more effective defense against secondary infection attempts, suggesting that locally induced resistance might play a role.

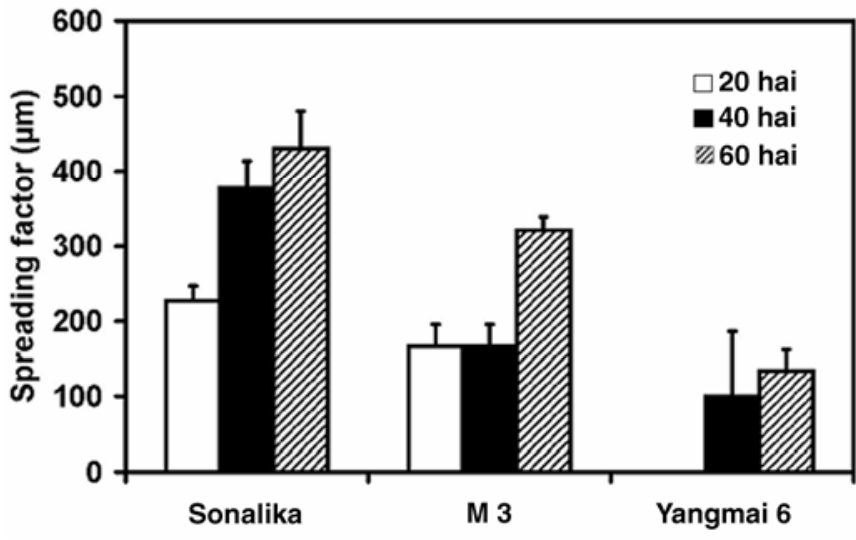

Fig. 6. Fungal development within the mesophyll tissue (spreading) of wheat genotypes Sonalika, M 3, and Yangmai 6. The degree of spreading of Bipolaris sorokiniana, isolate $B s-k n 2$, is specified as a spreading factor $(\mu \mathrm{m})$ by assessing the range of the most distant tips of hyphae at one infection site for the time points 20, 40, and $60 \mathrm{~h}$ after inoculation (hai). Thirty interaction sites were evaluated per leaf. The mean of three leaves for each genotype and inspection time point is displayed. The experiment was repeated two times with similar results. Vertical bars represent standard deviation of the mean.

TABLE 2. Electrolytic leakage of mesophyll tissue of wheat genotypes after inoculation with Bipolaris sorokiniana, isolate $B s-k n 2^{a}$

\begin{tabular}{lccccr}
\hline & Level of field & \multicolumn{4}{c}{ Time after inoculation } \\
\cline { 3 - 6 } Genotypes & resistance & $0 \mathrm{~h}$ & $24 \mathrm{~h}$ & $48 \mathrm{~h}$ & $72 \mathrm{~h}$ \\
\hline Yangmai 6 & $\mathrm{R}$ & 4.7 & 27.8 & 41.2 & 75.8 \\
Chirya 7 & $\mathrm{R}$ & 2.9 & 47.2 & 62.6 & 89.5 \\
Longmai 10 & $\mathrm{MR}$ & 7.5 & 32.2 & 51.1 & 100.3 \\
Sonalika & $\mathrm{S}$ & 6.6 & 43.4 & 90.8 & 161.2 \\
\hline
\end{tabular}

a MR, moderately resistant; $\mathrm{R}$, resistant; $\mathrm{S}$, susceptible. Comparison of means between genotypes using Games-Howell test: there is a significant difference between Yangmai 6 and Sonalika at $P<0.05$, but no significant difference between Yangmai 6, Chirya 7, and Longmai 10 at 48 and $72 \mathrm{~h}$ after inoculation (hai). Comparison of means between time after inoculation using paired $t$ test of repeated measures: there is a highly significant difference at all time points in Sonalika $(P<0.01)$. Yangmai 6 , Chirya 7 , and Longmai 10 also showed small but significant differences with time $(P<0.05)$. 


\section{ACKNOWLEDGMENTS}

This project was supported by the STIBET-Matching-Funds (Deutscher Akademischer Austauschdienst, DAAD, and BASF AG). We thank E. Duveiller for pedigree information and constant encouragement and S. Ali and G. Langen for advise.

\section{LITERATURE CITED}

1. Almgren, I., Gustafsson, M., Falt, A.-S., Lindgren, H., and Liljeroth, E. 1999. Interaction between root and leaf disease development in barley cultivars after inoculation with different isolates of Bipolaris sorokiniana. J. Phytopathol. 147:331-337.

2. Apoga, D., Akesson, H., Jansson, H.-B., and Odham, G. 2002. Relationship between production of the phytotoxin prehelminthosporol and virulence in isolates of the plant pathogenic fungus Bipolaris sorokiniana. Eur. J. Plant Pathol. 108:519-526.

3. Bidari, V. B., and Govindu, H. C. 1979. Germination and appressorial formation in Helminthosporium sativum on wheat leaf. Curr. Res. 8:154-155.

4. Briquet, M., Vilret, D., Goblet, P., Mesa, M., and Eloy, M.-C. 1998. Plant cell membranes as biochemical targets of the phytotoxin helminthosporol. J. Bioenerg. Biomembr. 30:285-295.

5. Büschges, R., Hollricher, K., Panstruga, R., Simons, G., Wolter, M., Frijters, A., van Daelen, R., van der Lee, T., Diergaarde, P., Groenendijk, J., Töpsch, S., Vos, P., Salamini, F., and Schultz-Lefert, P. 1997. The barley Mlo gene: A novel control element of plant pathogen resistance. Cell 8:1793-1807.

6. Dehne, H.-W., and Oerke, E. C. 1985. Investigations on the occurrence of Cochliobolus sativus on barley and wheat. Vol. 2. Infection, colonization and damage of stem and leaves. J. Plant Dis. Prot. 92:606-617.

7. Duczek, L. J., and Jones-Flory, L. L. 1994. Relationship between common root rot, tillering and yield loss in spring wheat and barley. Can. J. Plant Pathol. 15:153-158.

8. Duveiller, E., Garcia, I., Franco, J., Toledo, J., Crossa, J., and Lopez, F. 1998. Evaluating spot blotch resistance of wheat: Improving disease assessment under controlled conditions and in the field. Pages 171-181 in: Helminthosporium Blights of Wheat: Spot Blotch and Tan Spot. E. Duveiller, H. J. Dublin, J. Reeves, and A. McNab, eds. International Maize and Wheat Improvement Centre, CIMMYT, Mexico, D.F.

9. Duveiller, E., and Garcia Altamirano, I. 2000. Pathogenicity of Bipolaris sorokiniana isolates from wheat roots, leaves and grains in Mexico. Plant Pathol. 49:235-242.

10. Duveiller, E., and Gilchrist, L. 1994. Production constraints due to Bipolaris sorokiniana in wheat: Current situation and future prospects. Pages 343-352 in: Wheat in Heat-Stressed Environments: Irrigated Dry Areas and Ice-Wheat Farming Systems. D. A. Saunder and G. P. Hettel, eds. International Maize and Wheat Improvement Centre, Mexico, D.F.

11. Freialdenhoven, A., Peterhänsel, C., Kurth, J., Kreuzaler, F., and SchulzeLefert, P. 1996. Identification of genes required for the function of nonrace-specific mlo resistance to powdery mildew in barley. Plant Cell 8:514.

12. Grey, W. E., and Mathre, D. E. 1984. Reaction of spring barley to common root rot and its effects on yield components. Can. J. Plant Sci. 64:245-253.

13. Hetzler, J. 1992. Host-pathogen interactions in populations of Bipolaris sorokiniana in warm non-traditional areas. Ph.D. Thesis. Georg August University, Göttingen, Germany.

14. Hückelhoven, R., Fodor, J., Preis, C., and Kogel, K.-H. 1999. Hypersensitive cell death and papilla formation in barley attacked by the powdery mildew fungus are associated with hydrogen peroxide but not with salicylic acid accumulation. Plant Physiol. 119:1251-1260.

15. Hückelhoven, R., and Kogel, K.-H. 1998. Tissue-specific superoxide generation at interaction sites in resistant and susceptible near-isogenic barley lines attacked by the powdery mildew fungus (Erysiphe graminis $\mathrm{f}$. sp. hordei). Mol. Plant-Microbe Interact. 11:292-300.

16. Hückelhoven, R., and Kogel, K.-H. 2003. Reactive oxygen intermediates in plant-microbes interactions: Who is who in powdery mildew resistance? Planta 216:891-902.
17. Jain, S. K., Langen, G., Hess, W., Börner, T., Hückelhoven, R., and Kogel, K.-H. 2004. The white barley mutant albostrians shows enhanced resistance to the biotroph Blumeria graminis f. sp. hordei. Mol. PlantMicrobe Interact. 17:374-382.

18. Jarosch, B., Kogel, K.-H., and Schaffrath, U. 1999. The ambivalence of the barley Mlo locus: Mutations conferring resistance against powdery mildew (Blumeria graminis f. sp. hordei) enhance susceptibility to the rice blast fungus Magnaporthe grisea. Mol. Plant-Microbe Interact. 12:508-514

19. Knudsen, I. B. M., Hockenhull, J., and Jensen, D. F. 1995. Biocontrol of seedling disease of barley and wheat caused by Fusarium culmorum and Bipolaris sorokiniana: Effects of selected fungal antagonists on growth and yield components. Plant Pathol. 44:467-477.

20. Kumar, J., Hückelhoven, R., Beckhove, U., Nagarajan, S., and Kogel, K.H. 2001. A compromised Mlo pathway affects the response of barley to the necrotrophic fungus Bipolaris sorokiniana (teleomorph: Cochliobolus sativus) and its toxins. Phytopathology 91:127-133.

21. Kumar, J., Schäfer, P., Hückelhoven, R., Langen, G., Baltruschat, H., Stein, E., Nagarajan, S., and Kogel, K.-H. 2002. Bipolaris sorokiniana, a cereal pathogen of global concern: Cytology and molecular approaches towards better control. Mol. Plant Pathol. 3:185-195.

22. Kutcher, H. R., Bailey, K. L., Rossnagel, B. G., and Legge, W. G. 1994. Heritability of common root rot and spot blotch resistance in barley. Can. J. Plant Pathol. 16:287-294.

23. Kwon, C. Y., Rasmussen, J. B., Francl, L. J., and Meinhardt, S. W. 1996. A quantitative bioassay for necrosis toxin from Pyrenophora triticirepentis based on electrolyte leakage. Phytopathology 86:1360-1363.

24. Mehta, Y. R. 1998. Constraints on the integrated management of spot blotch of wheat. Pages 18-27 in: Helminthosporium Blights of Wheat: Spot Blotch and Tan Spot. E. Duveiller, H. J. Dubin, J. Reeves, and A. $\mathrm{McNab}$, eds. International Maize and Wheat Improvement Centre, CIMMYT, Mexico, D.F.

25. Nagarajan, S., and Kumar, J. 1998. Foliar blights of wheat in India: Germplasm improvement and future challenges for sustainable, high yielding wheat production. Pages 52-58 in: Helminthosporium Blights of Wheat: Spot Blotch and Tan Spot. E. Duveiller, H. J. Dubin, J. Reeves, and $\mathrm{A}$. McNab, eds. International Maize and Wheat Improvement Centre, CIMMYT, Mexico, D.F.

26. Olbe, M., Sommarin, M., Gustafsson, M., and Lundborg, T. 1995. Effect of the fungal pathogen Bipolaris sorokiniana toxin prehelminthosporol on barley root plasma membrane vesicles. Plant Pathol. 44:625-635.

27. Rohringer, R., Kim, W. K., Samborski, D. J., and Howes, N. K. 1977. Calcofluor: An optical brightener for fluorescence microscopy of fungal parasites in leaves. Phytopathology 67:808-810.

28. Schäfer, P., Hückelhoven, R., and Kogel, K.-H. 2004. The white barley mutant Albostrians shows a super-susceptible but symptomless interaction phenotype with the hemibiotrophic fungus Bipolaris sorokiniana. Mol. Plant-Microbe Interact. 17:366-373.

29. Sharma, R. C., Duveiller, E., Ahmed, F., Arun, B., Bhandari, D., Bhatta, M. R., Chand, R., Chaurasiya, P. C. P., Gharti, D. B., Hossain, M. H., Joshi, A. K., Mahto, B. N., Malaker, P. K., Reza, M. A., Rahman, M., Samad, M.A., Shaheed, M. A., Siddique, A. B., Singh, A. K., Singh, K. P., Singh, R. N., and Singh, S. P. 2004. Helminthosporium leaf blight resistance and agronomic performance of wheat genotypes across warm regions of South Asia. Plant Breed. 123:520-524.

30. Singh, R. V., Singh, A. K., and Singh, S. P. 1998. Distribution of pathogens causing foliar blights of wheat in India and neighboring countries. Pages 59-62 in: Helminthosporium Blights of Wheat: Spot Blotch and Tan Spot. E. Duveiller, H. J. Dubin, J. Reeves, and A. McNab, eds. International Maize and Wheat Improvement Centre, CIMMYT, Mexico, D.F.

31. Thordal-Christensen, H., Zhang, Z., Wei, Y., and Collinge, D. B. 1997. Sub-cellular localization of $\mathrm{H}_{2} \mathrm{O}_{2}$ in plants. $\mathrm{H}_{2} \mathrm{O}_{2}$ accumulation in papillae and hypersensitive response during the barley-powdery mildew interaction. Plant J. 11:1187-1194.

32. Van Ginkel, M. V., and Rajaram, S. 1998. Breeding for resistance to spot blotch in wheat: Global perspective. Pages 162-170 in: Helminthosporium Blights of Wheat Spot Blotch and Tan Spot. E. Duveiller, H. J. Dubin, J. Reeves, and A. McNab, eds. International Maize and Wheat Improvement Centre, CIMMYT, Mexico, D.F 